IKONOMIKA: Jurnal Ekonomi dan Bisnis Islam

Volume 3, No 2 (2018)

ISSN : 2527-3434 (PRINT) - ISSN: 2527-5I43 (ONLINE)

Page : I39- I66

\title{
Analysis Of Ta'awun Fund Model Best Practice From Indonesia
}

\author{
Dindin Jaenudin ${ }^{1}$, Achmad Firdaus ${ }^{2}$, Farit M. Afendi ${ }^{3}$, \\ Bayu Taufiq Possuma ${ }^{4}$ \\ STEI Tazkia ${ }^{1,23}$, Universiti Malaysia Terengganu ${ }^{4}$ \\ din2.asgar@gmail.com ${ }^{1}$, achmad.firdaus@tazkia.ac.id², fmafendi@gmail.com³ \\ btaufiq@gmail.com ${ }^{4}$
}

\section{ABSTRACT}

The Muslim population of Indonesia in 2010 reached 207 million, while the number of poor people reached 27,76 million. On the other hand, Indonesia is prone to natural disaster. By 2015 there are I6,830 villages hit by floods, 3,827 villages experiencing earthquakes, and 7,86I villages experiencing landslides. It is important for Indonesian people to pool fundraising to help each other (ta'awun). One of the schemes is through the microtakaful program. The next issue is the inability of the poor Indonesian to pay a pooling fund.

The research is conducted with the aim to analyze the appropriate model of microtakaful in Indonesia using infaq/sadaqah and zakah fund as an alternative payment of subsidy of microtakaful contribution. The research is conducted with several methods, namely the study of indepth literature on the utilization of infaq/sadaqah and zakah fund. The proposed models of utilization of infag/sadaqah and zakah fund to subsidy ta'awun fund, validate the model through interviews to experts, practitioners and fund managers, process the data through Analytic Network Process (ANP), and determine the best model in utilizing infaq/sadaqah and zakah fund to subsidy ta'awun fund. Fund management model to become the object of research are microtakaful model and subsidy fund from the government model.

The study shows that: Firstly, Ta'awun's fundraising in Indonesia is in line with the shariah objectives of protecting the soul, protecting religion, protecting intellect, protecting wealth, and protecting progeny. Secondly, the microtakaful model implemented in Indonesia is a microtakaful model by institution independently, a microtakaful model

Received :December 29, 2018 - Revised: December 3I, 2018 - Accepted: December II, 2018 STEI Tazkia ${ }^{1,23}$, Universiti Malaysia Terengganu ${ }^{4}$

E-mail:din2.asgar@gmail.com ${ }^{\mathrm{I}}$,achmad.firdaus@tazkia.ac.id², fmafendi@gmail.com³ 
with a subsidy from infaq/sadaqahfund, a microtakaful model with a subsidy from zakah funds, ta'awun fund management model with a subsidy from the government and microtakaful model with a subsidy from other institution. Third, an important component in microtakaful is aqad, participant, underwriting process, investment, donor party and facility needs. The proper aqad in ta'awunfundraising is mudharabahmusytarakah.The simple Underwriting process is required. Parties that act as donors are zakah institution and government. Participants as beneficiaries of the contribution are poor and needy.

Keywords : Microtakaful, Ta'awun, Zakah, Infaq, Sodaqah

\section{A. INTRODUCTION}

Indonesian Muslims in 2010 was 207 million people (BPS, 2016). The number will increase to 238 million in 2030 (Pew Research's Center, 20II: II). However, the number of poor people in 2016 reached 27,76 million people (BPS, 2017: 2 and 6). On the other hand, Indonesia is prone to natural disasters. Throughout 20I5, the flood-hit I6.380 villages, earthquakes shook 3.827 villages, and landslides buried 7.86I villages (BPS, 20I5). So, it is important for Indonesian people to raise funds to help one another (ta'awun). One scheme is through the microtakaful program.

Microtakaful products that are promoted in Indonesia consist of the card and non-card versions. The Financial Services Authority (2013) has issued provisions for card products, including the maximum contribution amount of $\mathrm{Rp}$ 50,000. For the non-card product, there is credit life insurance which covers financing customers, who are registered by microfinance institutions, when customers die, with a monthly contribution of $0.05 \%$ from the funding.

Since 2013, microinsurance and Islamic microinsurance programs (microtakaful) have been greatly socialized by the Financial Services Authority (OJK). The lower-middle-class society is targeted to be the participant. While in the Takaful scheme, the poor are still in the "not insurable" category (Sukmana and Hidayat, 20I4: 2). The microtakaful program is one of the strategies to alleviate the poverty (Patel, 2004: 17). Microtakaful has become an important supporter of sustainable poverty alleviation programs in the last few decades (Patel, 2012: 37). The next problem in Indonesia is the inability of the poor people to pay contributions. 
Hasim (20I4: 2320) suggested that the contribution of microtakaful is paid by the Regional Zakat Agency (BAZDA), either partial or the whole amount. More broadly the International Zakat Agency in collaboration with microtakaful companies uses zakat funds to enrol the participants from the poor and middleclass.

Infaq/sadaqah, zakat, and waqf are Islamic social charities. They are mainly aimed at poverty alleviation and empowerment (Ascarya, et.al., 20I6: I). Infaq/sadaqah and national charity experience growth every year. The total collection in 2016 amounted to $\mathrm{Rp} 4.739$ trillion, with the amount of infaq/sadaqah amounted to Rp I.0 trillionand zakah amounted to 3.7 trillion (Baznas, 2017: 6). This amount increased as compared to 2015, which amounted to Rp 3.846 trillion (Baznas, 2016: 5). The largest increase in the collection occurred in 2007 with an increase of $98.3 \%$. Furthermore, the average growth from 2002 to 2016 was $35.84 \%$ (figure I). The increase and growth of collection are influenced by several factors (Indonesian Zakah Outlook 2017, 2016: 46), such as:

I) The rise of public awareness to pay ZIS (Zakah, Infaq, Sadaqah) through official zakah bodies which are formed and/or recognized by the government,

2) The better ZIS reporting system at the national level, and

3) The rapid growth of middle-class (the fastest in ASEAN).

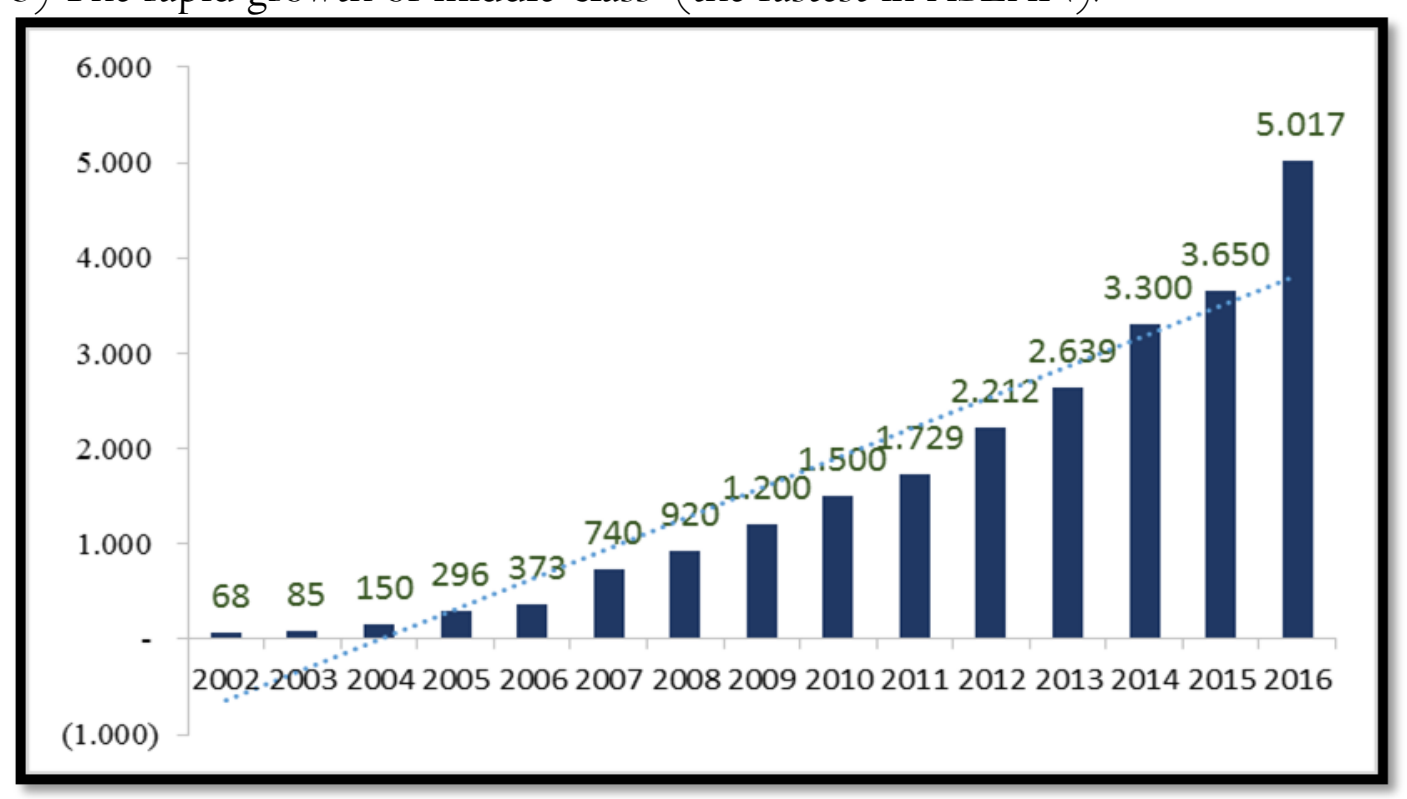

Source: Baznas, 2017

Figure I.

The National Infaq/Sadaqah and Zakah Collection Growth 
According to the above factors, the distribution of infaq/sadaqah and zakah in Indonesia should receive more attention. Currently, BAZNAS is creatively and innovatively managing zakah funds in various micro and small business financing. However, BAZNAS also still notice the possibility of a non-optimal distribution program (Indonesian Zakah Outlook 20I7, 20I6: 44). Related to the poverty alleviation programs in Indonesia, BAZNAS makes a breakthrough program, covers many groups, and collaborates with government and non-government institutions (Indonesian Zakat Outlook 2017, 2016).

Qardawi (I99I: 510) pointed out that the first and second zakah target is poor (fakir) and needy (miskin) as written in the Quran surah At Taubah verse 60. Distribution of zakah, other than for consumptive purpose, must be encouraged to be productive and investable. Therefore, zakah can be beneficial in reducing poverty and improving the welfare of the community.

In Indonesia, the role of microtakaful management has also been carried out by the Baitul Maal wa Tamwil (BMT) or Islamic Savings and Loan Cooperatives (KSPPS), either by managing independent funds or cooperating with Islamic Insurance Companies (Masrifah, 2016: 3-4).

The prospect for insurance growth in Indonesia is still promising, including through the development of microtakaful. Business Monitor International (BMI) in Islamic Insurance Outloook 2017 (2017: 7) quoted that:

"The insurance sector in Indonesia is one of the fastest growing in the Asia Pacific region and offers the potency of significant growth in the future. Indonesia is home to a large population, while the average household income in many regions is relatively low. Gradual expansion from the middle-class, growing income levels, and the growth of more affordable insurance products including microinsurance, all of them indicating a positive environment for the development of life insurance and non-life insurance. Therefore, nowadays we see more and more global insurance companies take advantage of the Indonesian market, they enter either as newcomers or through local acquisitions against the relatively fragmented markets".

Moreover, research by Erblbeck, et.al. (20II: 2) found that the best microinsurance practice services could be offered in an Islamic way. Erblbeck, et.al. (20II: 25) also concluded that microtakaful provides a promising perspective for the development of the Islamic insurance markets in the future and ultimately contributes to a country's economic growth. 


\section{B. THEORITICAL}

\section{Islamic Microinsurance (Microtakaful)}

Microtakafulis defined as a mechanism to provide shariah-based protection for disadvantaged Muslims at affordable prices (Gor, 2013: 18). Microtakā fulis also defined as a mechanism to provide shariah-based protection to blue-collar and disadvantaged people at affordable prices (Takaful Africa Insurance, 20I2: I0). Another definition of microtakaful is a joint initiative, in which a group of participants agreed to support each other for losses arising from the determined risks, under Tabarru' principles (donations), Ta'awun(mutual help/assistance) and the prohibition of riba (usury). Microtakā fulis generally offered to low-income and disadvantaged segments of the population (which are usually excluded from general Takā ful terms and conditions) by various entities regulated and supervised by Takā ful/insurance supervisory and authorities or other competent authorities under the national law (IFSB and IAIS, 20I5: 4).

Microtakaful, according to Abdelkader (2013: 223), is protection against risks that cannot be predicted by the borrower, microinsurancetakes the form of microtakaful based on mutual guarantees. The contribution of each member to the insurance fund helps them to improve the risks prevention and strengthen the security of borrowers. This fund compensates borrowers in the case of emergencies - such as fire accident, floods, agricultural losses and death - that affect their businesses.

Swartsz, et.al. (20I0: 337) described microtakaful as one mechanism to meet low-income people's needs, with the concept of providing affordable protection for the poor. Islamic insurance operators must provide this kind of product, as an alternative product to the society that is offered in conventional markets.

Based on the above definitions, microtakaful can be defined as an alternative to microinsurance services with a shariah contract for an underprivileged community (which is excluded from takaful), which was born from the mutual agreement to help each other (Ta'awun) from the risks of loss or certain calamities that befall the community.

\section{Infaq, Sadaqahand Zakah}

\section{a. Infaq}

Sarwat (2016: 30) explained that the infaq comes from the Arabic language, which means expends or spends the wealth. In Arabic, "infaq" is still very common, it can be used for a good or bad purpose. The point is to spend the 
wealth or spend the assets. The purpose can be for goodness, donations, or something that is for yourself, or even for the consumptive purpose.

\section{b. Sadaqah}

Sarwat (2016: 32) explained that sadaqah comes from the Arabic language, (صدقة) which has a similar meaning to the term infaq, but more specific. Sadaqah is to spend assets or to issue funds to get closer to Allah, that is to say for worship or good deeds. Ar-Raghib al-Asfahani defines sadaqah as:

"Assets issued by someone to get closer to Allah."

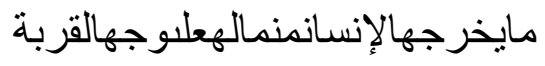

\section{c. Zakah}

Qardawi (2006: 34) stated that Zakahin terms of language means holy, growing, blessing, and commendable. After prayer, zakah is a very important rule of Islam. The meaning of zakahis purity and increase. In other words, by paying zakah, someone purifies his wealth and also having religious obligation against his wealth (Kailani, I998: I0).

According to Syahatah (2004: 7), zakahplays an important role in economic development, namely contribute to alleviating the poverty of the poor and turning them into productive forces, as zakahalso has social sides when it contributes to realizing the adh-dhaman al-ijtima'I (social security). Ministry of Religion of Indonesia (2013: 7-8) notes some elements that must be met by zakah: the giving, material possessions, a group of people as recipients, measurement (nishab), anddesignated time.

From some of the descriptions above, zakah has an important position for every Muslim. Zakah can save oneself yet becomes a sin for those who do not fulfillit. According to the social dimension, zakah that is paid by Muslim can help the surrounding community, yet the zakah should also meet certain criteria.

Zakahis distributed through zakah collector body (amil). The distribution of zakah that is not through amilzakah will lead to the decrease in its urgency of the benefits, and there is the tendency that the funds will run out quickly (for consumptive purposes). Consequently, zakah funds cannot help education, health, and economic empowerment (FOZ, 20I2: II).

\section{Reach the MaqashidShariah with Mikrotakaful}

To achieve the highest happiness (Falah), every Muslim should fulfill the maqashid shariah (Aziz and Mohamad, 2013: 5). Maqashid Shariah means the goals and objectives of Islamic legislation. The maqashid shariah classification according to the scholars is divided into three categories: 
I. Dharuriyyat (important), which means protection of 5 things (faith/religion, intellect, wealth, human self, and progeny).

2. Haajiyyat (complement), and

3. Tahsiniyyat (decoration).

Qasada is the root word of Maqashid. It can be interpreted as having an intention, take the middle road and walk towards some point. The word also comes from the noun Qasd, which means a goal or aspiration. Whereas Shariah is a noun which means the path to the waterhole, or for its general use is to the law of Allah Subhanahuwata'ala as revealed to the Prophet.

Mikrotakaful can fulfill maqashid shariah and is used to protect oneself, property, family, and more broadly to help the other Muslims (Aziz and Mohamad, 2013: 2I). Mikrotakaful eliminates prohibited elements in conventional insurance, such as: uncertainty (gharar), gambling (maisir), interest (riba), tyranny (adz-dzulm), bribe or kickback (risywah), cheating (tathfif), immoral behavior and haram insurance objects (Sula, 20I6). The concept of mutual guarantee (takaful) and mutual help (ta'awun) is one form of righteousness if there are participants got an accident or suffer the loss from a disaster (Sula, 2016: 99).

Iqbal (20I4:6) that microtakaful is a "risk sharing" that aimed at people above the poverty line. Ascarya's study, which used ANP (2015: I5), found that microtakaful is highly needed in Islamic microfinance services to let the mustahik to develop and expand their microbusiness by obtaining priority values $(2.17 \%)$.

\section{Microtakaful Model Elements Based on Funding Sources}

Decomposition results of the problem were obtained from interviews with experts and practitioners and literature review on infaq/sadaqah, zakah, and microtakaful. From the decomposition of the problem, an ANP model framework is formed (Figure 2). The ANP framework model developed in this study consists of several clusters, namely the objective cluster, criteria cluster, 6 sub-criteria clusters, and alternative clusters :

I. The objective cluster is the highest cluster in the ANP network which consists of objective elements that can be achieved with microtakaful. Objective cluster consists of Protecting Religion (hifz ad deen), Protecting Intellect (hifz al'Aql), Protecting Property/Wealth (hifz al maal), Protecting the Soul (hifz annafs), and Protecting Progeny (hifz an-nasl).

2. Criteria clusters consist of elements that support the implementation of the financial system smoothly.Criteria cluster consist of Akad/Contract, Underwriting, Investment, Participants, Donor Support, and Facility Needs. 
3. Sub-criterion clusters are clusters derived from the criteria cluster consisting of elements having the same number of criteria clusters. Sub-criterion clusters consist of :

a. The sub-criteria for Akad/contract consist of Mudharabah, Wakalah, Waqf, Wakalahbil Ujrah, Musyarakah, and Mudharabah Musytarakah.

b. Underwriting sub-criteria consist of simple, small value of the benefit, easyto-understand language, comprehensive, the great value of benefits, and difficult-to-understand language.

c. Investment sub-criteria consists of Deposits in Islamic Banks, Islamic Stocks, Sukuk/Islamic Bonds, Islamic State-Securities, Islamic Mutual Funds, and Pure Gold.

d. Participant sub-criteria consists of Fakir, Miskin, Ibn Sabil, Mualaf, Gharimin, and Fi Sabilillah.

e. The Donor Sub-criteria consists of the Government, Islamic Banks, Insurance Companies, Zakah collector agency, Private Companies, and Educational Institutions.

f. Facilities needs sub-criteria comprises of System (IT), Communication and interaction with Donors, Experts Human Resources, Financial Guidance, Supervisory Institutions, and Product Innovations.

4. The alternative cluster is the lowest cluster in ANP network consisting of microtakaful model elements. The alternative cluster consist of : Model I, Model 2, Model 3, Model 4, and Model

5. Elements of microtakaful models based on funding sources based on MaqashidShariah above can be seen in the framework below (figure 2). 


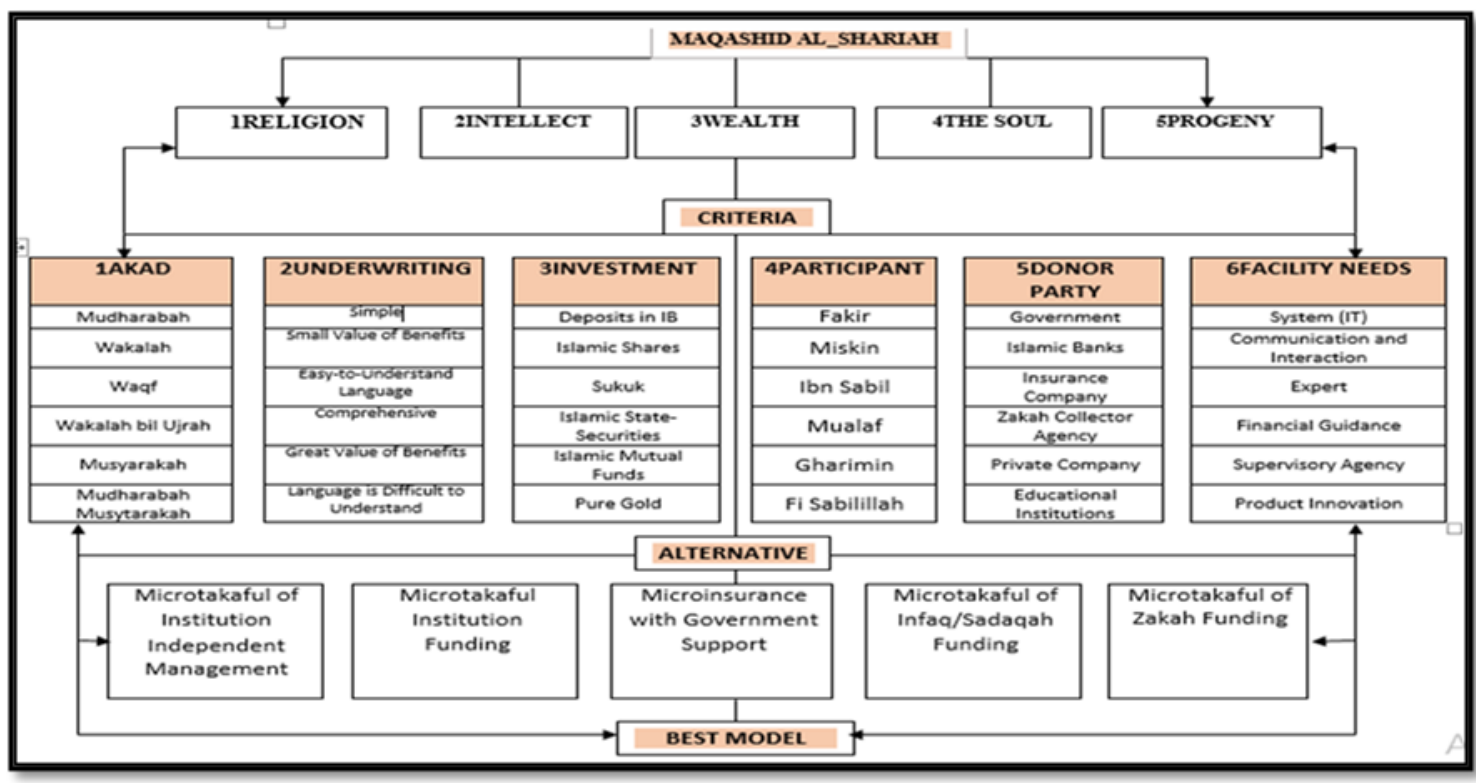

Figure 2

Framework

\section{METHODOLOGY}

From the above framework, ANP Network can be built as follows:

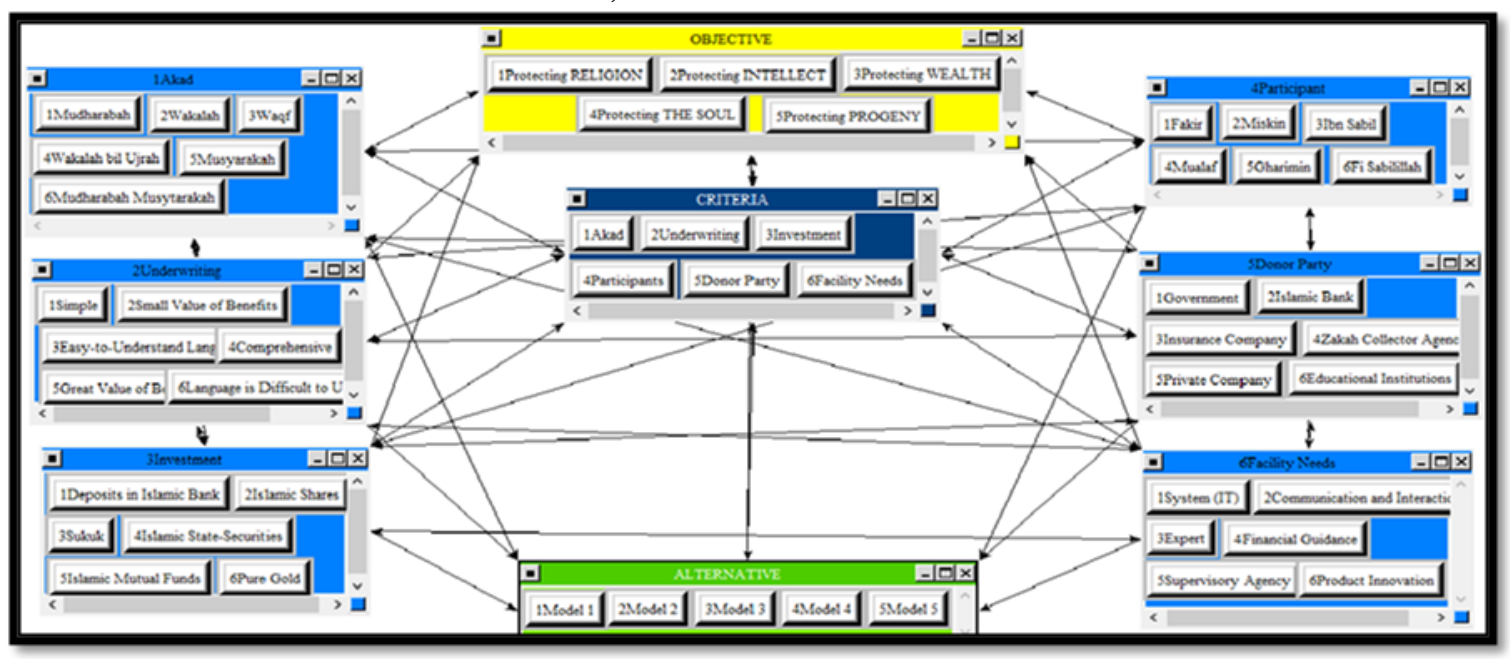

Figure 3

ANP Network

This study is qualitative research to choose the priority of microtakaful model. This study uses the Analytic Network Process (ANP) to determine the criteria, sub-criteria and the most important alternative models. Furthermore, the data is processed with the "Super Decision" software. 
The data used in this study consists of:

I. The primary data from interviews (in-depth interview) with the experts and experienced practitioners in the zakat and microtakaful area. The data is also obtained from the results of the questionnaire given to the experts and practitioners.

2. The secondary data which was obtained by researchers from the books, research reports, and scientific journals that discuss zakat and microtakaful.

The population of this study were 7 experts in infaq/sadaqah and zakah, and

Islamic microfinance. The experts have adequate knowledge and have been known well by the community. The experts consist of:

I. Didin Hafidhuddin, one of the reformist figure of infaq, sadaqah and zakah movements in Indonesia;

2. Hendri Tanjung, one of the initiator of Islamic economics and Islamic microfinance institutions;

3. M. Hasbi Zaenal, one of the movers of zakah and active in the National Zakat Agency (BAZNAS);

4. Ali Sakti, one of the drivers of shariah financial institutions and shariah microfinance institutions and is active at Bank Indonesia;

5. M. Nafik Ryandono, one of the drivers of shariah economy and sharia microfinance institutions and is active as a lecturer at the Airlangga University;

6. Priyonggo Suseno, one of the drivers of Islamic economics and Islamic microfinance institutions and is active as a lecturer at the Indonesian Islamic University; and

7. Agus Haryadi, pioneer and activist of Islamic insurance (takaful) and Islamic microinsurance (microtakaful) in Indonesia and active in the National Shariah Council of the Indonesian Ulema Council.

The data collected is processed by using ANP. Analytic Network Process (ANP) to model a problem, one needs a hierarchic or a network structure to represent that problem, as well as pairwise comparisons to establish relations within the structure(Saaty and Vargas, 2006:2).

Ascarya (2013: 9) explained that ANP does not require the assumption of element independence at a higher level than the element at a lower level and the independence of elements at the same level. The ANP also does not require the levels determination, only determines the network, unlike the Analytic Hierarchy Process (AHP). It is because the concept of ANP is an influence, while the main concept of AHP is which factor is more preferable. 
Tanjung and Devi (20I3: 2I2) wrote on the ANP model that was made by the facts taken from the theory of literature review, opinions and ideas of experts and competent practitioners. Therefore, ANP has the least assumption.

Ascarya (20I4: II) stated that the research which uses ANP requires 3 phases. More details are shown in Figure 4:

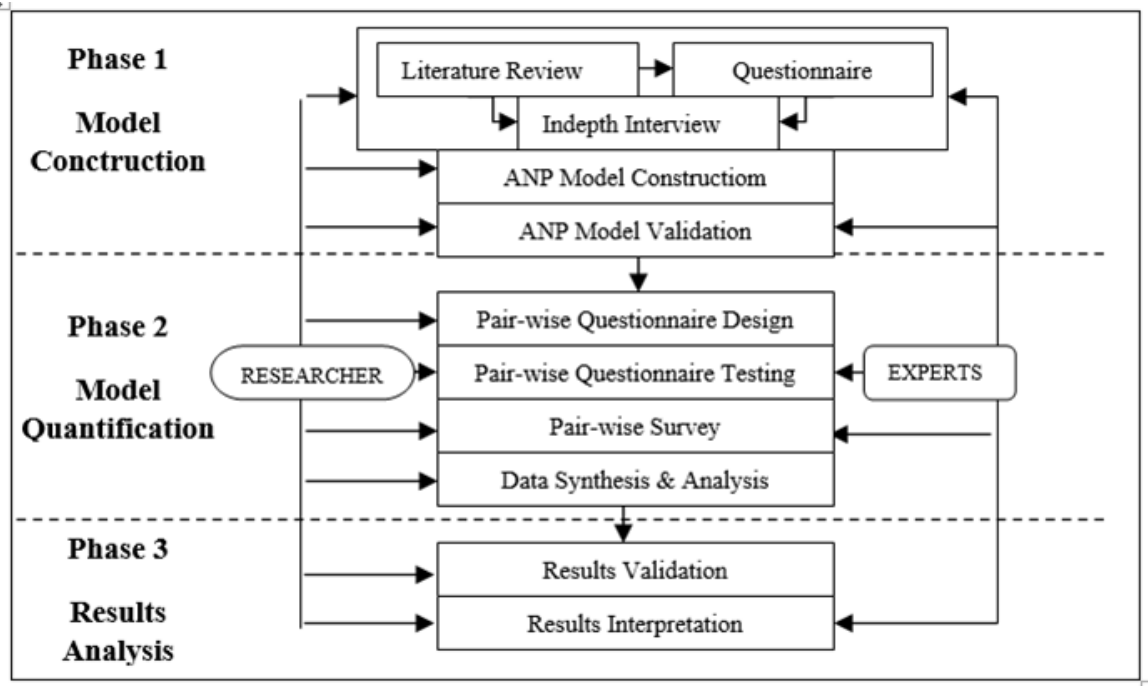

Source: Ascarya, 2014

Figure 4.

Stages of Research Using ANP

\section{RESULTS AND DISCUSSION}

\section{Results of Prioritization of Microtakaful Models in Indonesia}

a. Results of the ANP Operationalization - Objective Cluster (Maqashid Shariah)

This study will explain the priority results of the main objectives and criteria in operational microtakaful models and find the type of microtakaful model that has priority based on the ANP (Analytic Network Process) method approach with the feedback network.

This study uses seven respondents. RI shows the first respondent, R2 shows the second respondent, R3 shows the third respondent, R4 shows the fourth respondent, $\mathrm{R} 5$ shows the fifth respondent, $\mathrm{R} 6$ shows the sixth respondent, and R7 shows the seventh respondent. The geomean value shows the value of the results of the entire respondent. There are five shariah objectives, namely Protecting Religion (hifz ad Deen), Protecting Intellect (hifz al-'Aql), Protecting the 
property/wealth (hifz al Maal), Protecting the Soul (hifz an-Nafs), and Protecting Progeny (hifz an-Nasl).

The result of ANP processing, in general, shows that following the microtakaful program is one of the ways to protect the objectives of shariah. Figure 5 shows individual assessments and consensus results. The result of the consensus states that Maqashid Shariah with the most important priority isprotecting the soul $(23.4 \%)$. It is followed by protecting the faith/religion (22.4\%), protecting intellect (I8.0\%), protecting the wealth (I6.3\%) and protecting progeny (I4.9\%). The Maqashid Shariah sequence is not like its original priority, which is protecting faith/religion, protecting intellect, protecting the wealth, protecting the soul, and protecting progeny. The agreement of respondents $(\mathrm{W}=0.47 \mathrm{I})$ indicates a strong agreement among experts. The respondent's agreement shows that protecting the soul (hifz an-Nafs) is the main goal of someone joining themicrotakaful program. The respondents said that protecting progeny (hifz an-Nasl) is not very crucial in the microtakaful program.

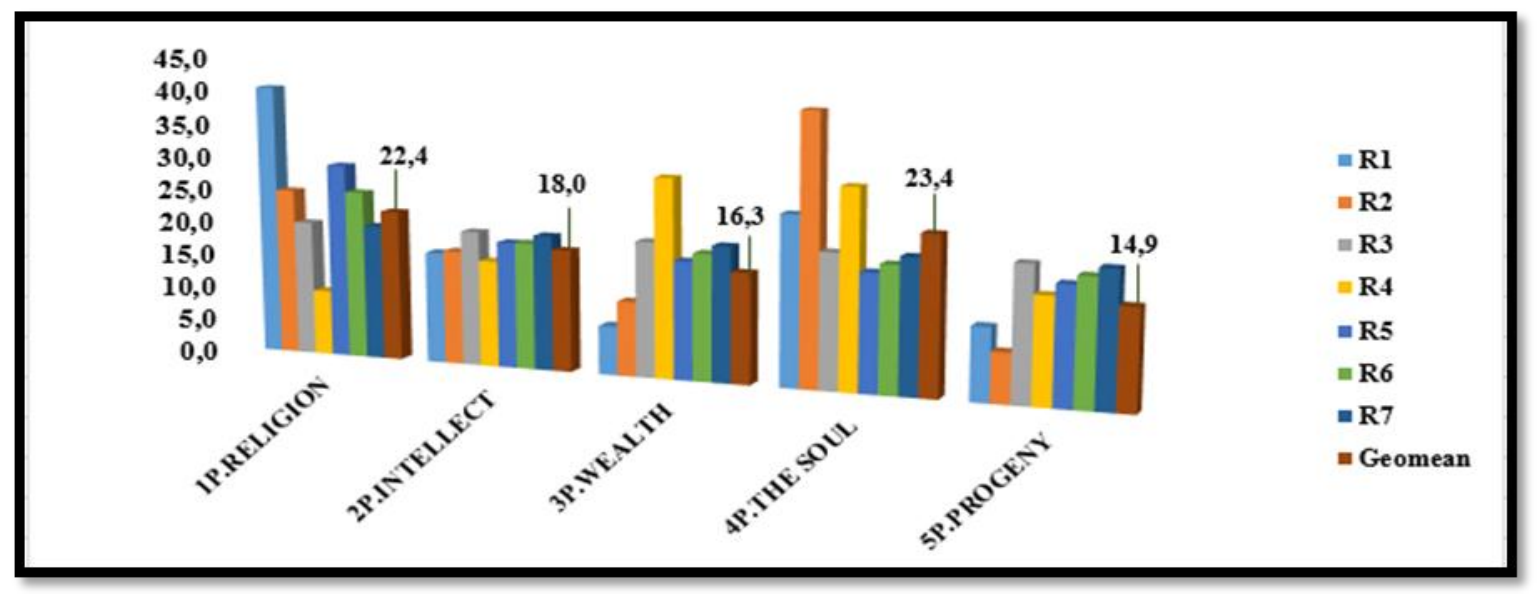

Figure 5

\section{ANP Result for Maqashid Shariah Aspect}

\section{b. Results of the ANP Operationalization - Criteria Cluster}

Figure 6. shows individual assessment and consensus results. The consensus result shows that the criterion with the most important priority is Akad (20.6\%). Then it is followed by Participants (I8.6\%), Underwriting (I8.4\%), Investment (I2.8\%), Donor Support (I0.4\%), and Facility Needs (8.5\%). This is also reflected in the high appraisal agreement $(W=0.396)$. Akad or Contracts are made for things that are justified by Islamic law (Ibdalsyah and Tanjung, 20I4: 
5I), including microtakaful. Each muamalah transaction cannot be separated from the akad/contract.

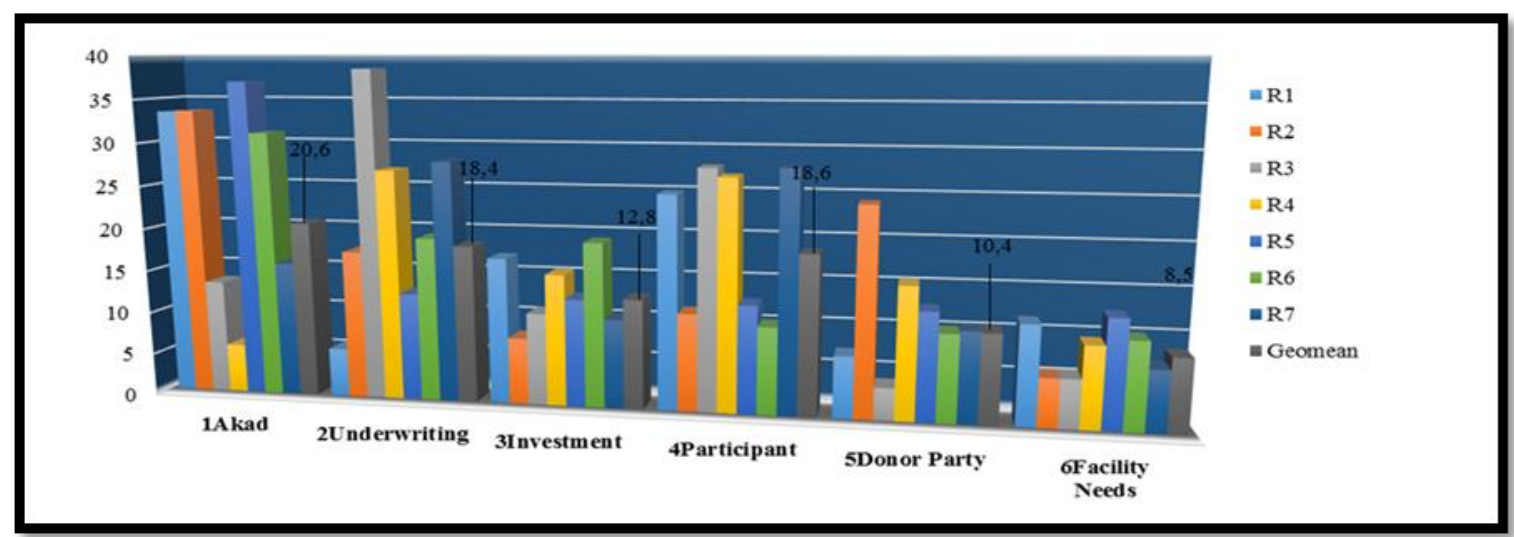

Figure 6.

ANP Result of Criteria

\section{c. Results of the ANP Operationalization - SubCriteria Cluster}

Figure 7 shows individual judgment and consensus results. The result of consensus shows that the element with the most important priority Mikrotakaful Model (above 20\%) is mudharabah musytarakah (Akad) (53.8\%), simple and easy-to-understand language (Underwriting) (26.8\%), zakah collector agency (Donor) (25.0\%), the needy (Participants) (24.1\%), the poor (Participants) (23.9\%), systems (IT) (Facility Needs) (23.3\%), skilled human resources (Facility Needs) (2I.3\%) and government (Donor) (20.1\%). Meanwhile, the sukuk element (Islamic bonds) and the deposit element in Islamic banks (Investment) with consensus value is below 20\%. All 6 (six) aspects have high appraisal agreements, especially Participants $(\mathrm{W}=0.650)$ and Underwriting $(\mathrm{W}=0.53 \mathrm{I})$.

Mudharabah musytarakah contract is also called a hybrid contract (Sula, 2016: 246). Investment funds in the Mudharabah musytarakah contract can be divided into two categories: company capital account and tabarru' fund account (Sula, 2016: 263). In the Mikrotakaful Model of Institution Independent Management (Model I), Tabarru' funds which derived from the payment of participant contributions can all be allocated to help each other. Revenue for the institution as the fund manager is taken from the investment profit sharing which consists of the profit sharing of the institution as mudarib (manager) and the profit sharing of the institution as musytarik (equity participation). Eventually, the remaining profit sharing after deducted by the rights of the institution is shared with the mikrotakaful participants. 
Unlike the Microtakaful Management Model which involve Islamic insurance companies, there is an allocation of ujroh for Islamic insurance companies which derive from contributions. The revenue of Islamic insurance companies were also obtained from investment profit sharing: firstly, the profit sharing of Islamic insurance companies as mudarib (managers) and secondly, the profit sharing of Islamic insurance as musytarik (equity participation). The remaining of the profit will be shared with each participant.

For Underwriting, simple and easy-to-understand language, as well as the characteristics of microtakaful products $(\mathrm{OJK}, 2017)$ being the priority that must be applied. Ahmed (2016: 4) stated that the difference between underwriting in microtakaful and non-micro lies in its simple acceptance process of the participants (no medical examination or form submission), and the policy that uses an easy-tounderstand language that can be received even by people with low level of education.

The investments that are prioritized are Sukuk (Islamic bonds) and deposits in Islamic banks. Sukuk has the advantages because there is an element of investment cooperation, risk sharing, and the involvement of real assets or projects as the underlying of the transaction (Musari, 20I5: I). Sukmana and Hidayat (20I4: I) pointed out that sukuk or Islamic bonds have an important role and become the driving force of the economic development. Furthermore, deposits in Islamic banks provide certainty of the saved funds, and the profit sharing can be taken within a certain period. Ismal (2013: 484) asserted that Islamic bank deposits in Indonesia can provide a competitive profit sharing.

In line with the study of Rom and Rahman (2012: I36), the poor and needy people are prioritized to be the microtakaful participants with various funding models for payment of contributions, especially the fund from zakah or infaq/sadaqah. Qardawi (2006: 5I4) stated that the poor and needy people are those who meet one of these three criteria:

I. People who do not have property and business;

2. People who have property or business but are not sufficient for themselves and their families. Their income does not meet half or less than the family need; or

3. People who have assets or businesses that can only fulfill half or more of the needs for themselves and their dependents, but not for all their needs.

The zakah collector body and the government are donors who are prioritized in supporting the payment of the contribution of microtakaful. The microtakaful model proposed by Hasim (20I4: 2324) is a microtakaful model that requires synergy and support from the zakah collector body (amil) and government 
agencies. The support is especially needed from the government, with its strength and policies, it must optimize the collection of zakat through one door, namely the Ministry of Waqf and Religious Affairs.

System (IT) and expert human resources are the priority of the facilities needs to support the operation of microtakaful. Microtakaful management and services must use a reliable (IT) system and expert human resources who understand microtakaful. Without the support of the microtakaful system (IT) and experts, the service offered will be the same as non-micro insurance. The number of participants spread to the remote areas must be accessible by using the System (IT), so the membership and claim process can run smoothly. Rusdydiana and Devi (2017: 275) argued that the system (IT) is essential to increase business capacity and to complement the needs of consumers. As for the microtakafu expert human resources, they will provide a service pattern that is different from the non-micro insurance mindset.

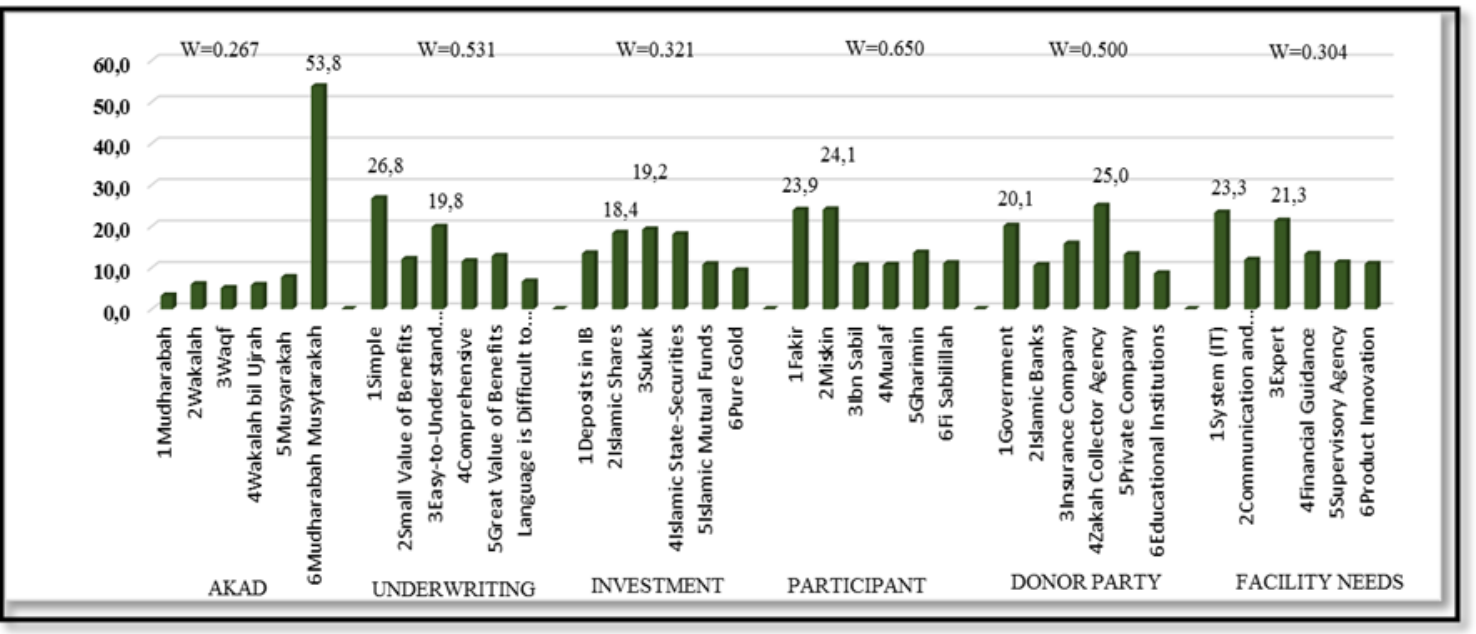

Figure 7

ANP Result of Sub-criteria

\section{d. Results of the ANP Operationalization - Alternative Cluster}

There are five elements in the alternative cluster consisting of:

I) Model I: Microtakaful of Institution Independent Management (PBMT Ta'awun-DI Yogyakarta)

This model is the management model of mutual help fund that is carried out independently by the institution without collaboration with Islamic insurance companies. Participant contributions for mutual help funds derive from each participant who is a member of BMT. 


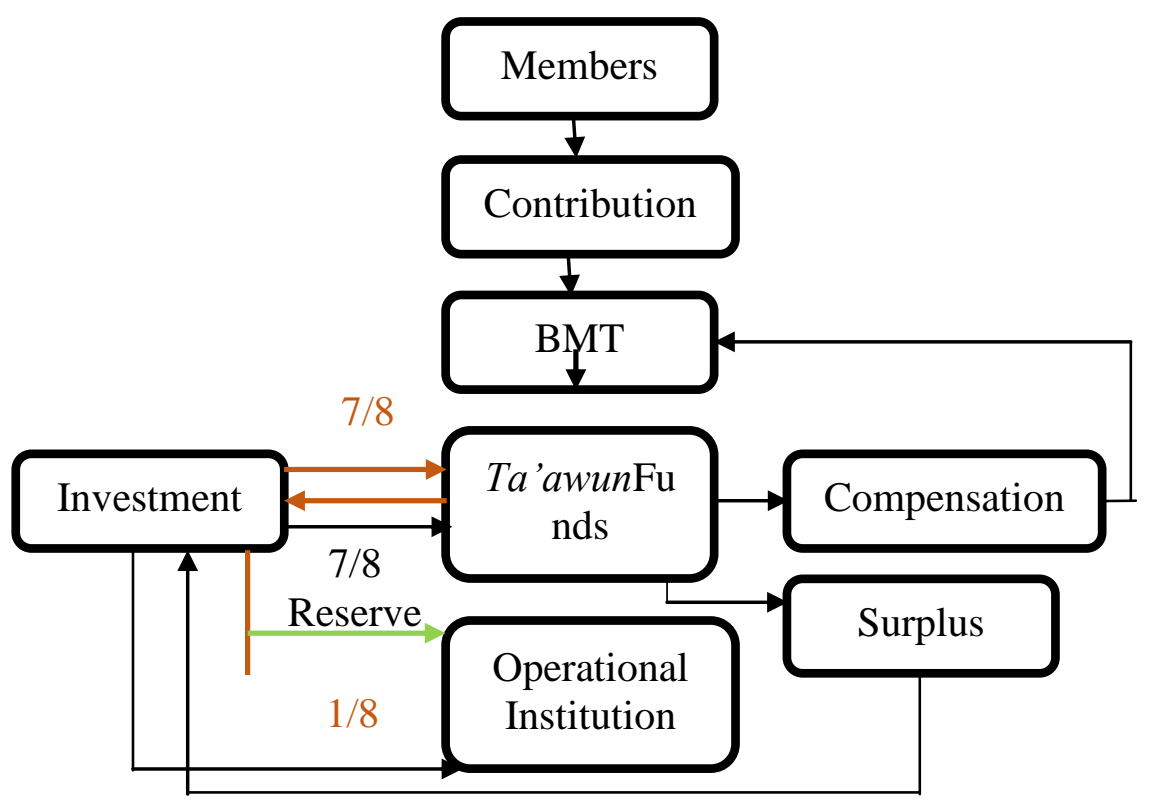

Figure 8

\section{Microtakaful Model - Independence Institution}

Microfinance institutions in Indonesia are quite beneficial to the society. However, currently, the existing microfinance institutions still do not have standard operational services to their customers. Therefore, it is encouraged to BMTs in Indonesia to form the BMT Association. PBMT Indonesia strives to improve institutional, operational and educational capacity, and training for its members including education and training through the establishment of the PBMT InstituteYogyakarta, PBMT Ventura-Jakarta to assist the BMT liquidity, and PBMT Accreditation to produce Islamic Microfinance Standards for BMTs ( Santoso, 2017).

Not all microfinance institutions in Indonesia have cooperated with Islamic insurance companies. Some of the reasons are: the value of losses/calamity of members is still small, the contribution of microtakaful cannot be recovered if there are claims, the limited ability of members to pay contributions, the provisions of shariah insurance that have not fully accommodated the needs of the institution, and the risk of loss is quite high on assets of BMT customers (Santoso, 2017). Sukmana and Hidayat (20I4: 2) argued the same, Islamic insurance companies still consider that microfinance institutions are not yet worth insuring. This is due to several factors, such as the members of microfinance institutions mostly come from low-income family or unemployed, the small amount of financing and the small number of insurance participants. Moreover, Bakhtiari (2013: 97) added some 
other factors such as the scattered communities, low level of education and limited assets.

PBMT Indonesia took the initiative to establish PBMT Ta'awun to manage risks collected from several BMTs who were members of the BMT Association. It is the risk of death and the fire accident in the place of business of BMT members (Santoso, 2017). It helps microfinance institutions (BMT) to get funds because members who borrow some funds get a guarantee and security if the risk occurs (Ahmed, 2016: 2). Initially, the program had been named Ta'awun Financing from the year 20II to April 2016 and had been managed directly by PBMT Ventura before Ta'awun PBMT was born in May 2017.

Each BMT collected the contribution of microtakaful from members who did murabahah financing to the Baitul Maal wat Tamwil (BMT). The rates charged to the members is $0.5 \%$ of the financing value, which is divided into two categories, $0.2 \%$ for death and $0.3 \%$ for a fire accident in the place of business (Santoso, 2017). This contribution is dedicated to mutual help fund (ta'awun) for BMT members who die and have a fire accident in the place of business. Then the institution collects microtakaful contributions from all BMTs to be managed by the institution. In this model, the institution regulates all aspects of microtakaful itself. All members are registered to be the microtakaful participants, all the claims will be paid according to the institution policy, and the allocation of ta'awun funds, whether to be invested or not is fully determined by the institution (Santoso, 2017).

If the ta'awun funds are invested by the institution to deposit at BMT, then the return on investment is divided by $7 / 8$ parts to be redistributed to the ta'awun fund and I/8 parts will be used as an operational expense of the institution, such as employee salary, electricity, telephone, and other expenses (Santoso, 2017). This practice is different with the Islamic insurance operations that take operational funds (wakalah fee) in advance which derives from gross contributions received by Islamic insurance companies, called ujroh (Sukmana and Hidayat, 20I4: 3).

For the return on investment of $7 / 8$ as mentioned above, if there is a remaining of the surplus from Ta'awun funds, it will be invested in the form of the deposit by the institution. The investment results are to be redistributed by $7 / 8$ parts for reserve funds and I/8 parts for institution operational funds (Santoso, 2017). In the Islamic insurance company, the ta'awun funds surplus refers to the Islamic insurance fatwa and the existing Islamic insurance regulations. The first alternative, all the surplus is allocated to tabarru' funds. The second alternative, some of the surplus is allocated to tabarru' funds and some to the participants. 
The third alternative, the surplus is allocated to tabarru' funds, to Islamic insurance companies and to participants (Fatwa DSN MUI No. 53 / DSN-MUI / III / 2006: 6).

Ta'awun funds will be accumulated for the purpose of mutual help in BMT throughout Indonesia who are actively participating in the ta'awun program. Currently, there are 350 BMT registered with institutions, but not all of them have joined the ta'awun institution program (Santoso, 2017).

In the case of claims for death, the institution will pay to BMT as much as the remaining debt of members to BMT before the death. As for fire accident compensation claims, the remaining financing (debts) of members will be paid by the institution to BMT. However, in the fire accident compensation claim, there is a process of verifying the fire damage. If the result of verification of fire damage is $50 \%$, then the compensation claim paid by the institution to BMT is $50 \%$ of the remaining financing (debt) of the member (Santoso, 2017). Some of the risks that communities often experience are death, fire accident, illness and others (Ahmed, 2016: 2).

In the condition of the deficit ta'awun fund (Santoso, 2017), the institution has prepared the following rules:

I. claims for compensation to members are taken from the institution's operational funds; or

2. if there is no ta'awun fund left, then there is no obligation to provide compensation claims to members.

The above deficit rules are different from the management of ta'awun on Islamic microinsurance, the deficit should be covered by the company using Qard (loan) funds and the return is taken from tabarru' funds (Fatwa DSN MUI No. 53 / DSN-MUI / III / 2006: 7 ).

\section{2) Model 2: Mikrotakaful Institution Funding (KSPPS BMT Itqan)}

This model is the management model of mutual help fund that is carried out by the institution in collaboration with the Islamic insurance companies. Participants' contributions are paid by policyholders, usually in the form of microfinance institutions. 


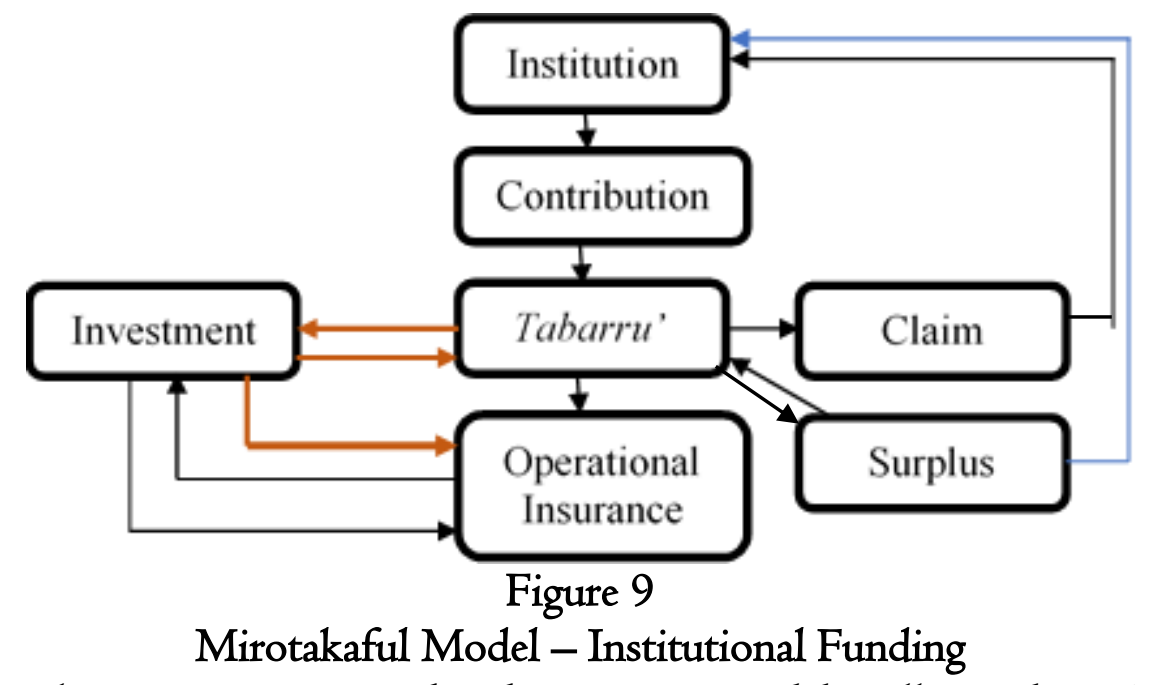

In Islamic cooperatives, the shares are owned by all members. Therefore, members are required to have obligatory savings and principal savings. As an added value, the Islamic cooperative provides compensation for death to all of its members. So that when a member dies, the Islamic cooperative disburses the obligatory savings, principal savings, and compensation for death. However, microtakaful contribution funds are paid from the income of Islamic cooperatives, not from cooperative members (Suryadi, 2017). This is in line with the statement of Sukmana and Hidayat (20I4: 8) that one of the Islamic microfinance institutions that apply microtakaful is a cooperative, but there are still many Islamic microfinance institutions that still have not implemented it. In line with the above opinion, Masrifah (2016: 30) stated that Islamic cooperatives or BMT indeed develop and manage ta'awun funds for unforeseen calamities. And this has become one of the uniqueness and characteristics of Indonesian Islamic Cooperatives or BMT compared to other Islamic microfinance institutions in the world (Masrifah, 2016: 48).

The role of Islamic cooperatives is to register all of its members to the Takaful company and pay contributions at a rate of $0.5 \%$. Consequently, the members can get the compensation for death, either due to an accident or not. The management of microtakaful is fully managed by Islamic insurance companies, and there is an age limitation of participants, for underwriting aspect, who are registered up to 60 years, and investments and claims are made by Islamic insurance companies (Suryadi, 20I7). 


\section{3) Model 3: Microinsurance with Government Support (PT Jasindo Insurance \& Ministry of Agriculture)}

The model is organized by the cooperation of conventional insurance companies and government to protect rice farmers and cattle farmers. Premiums are mostly paid by the government, and the remaining amount is paid by the rice farmers and cattle farmers.

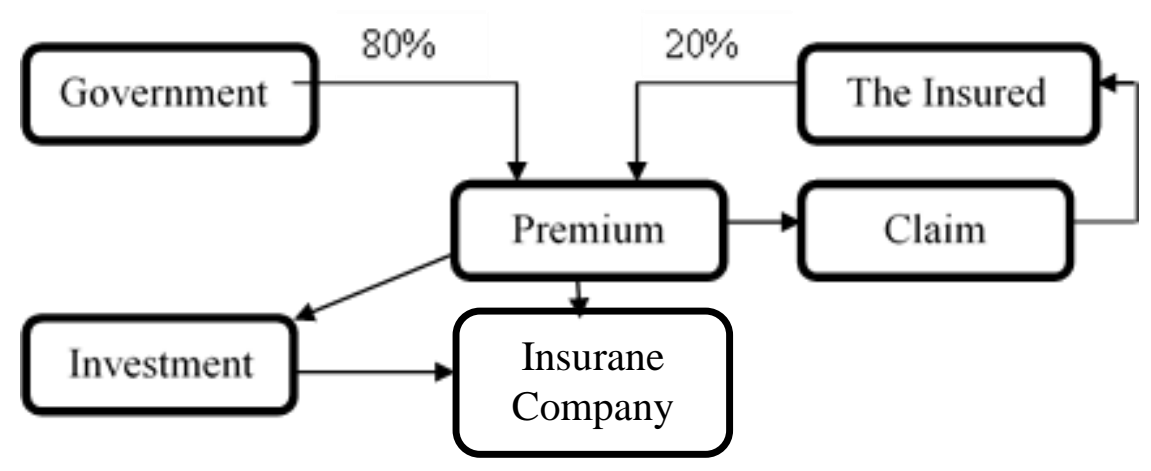

Figure 10

\section{Microinsurance Model with Government Support}

Microinsurance programs which are established by the government are based on the Law No. 19 the Year 2013 concerning the protection and empowerment of farmers. The risk in agricultural that must get protection from agricultural insurance is the risk of loss from crop failure, which can be caused by natural disasters, plant pest attack, outbreaks of infectious animal diseases, climate change impacts, and other risks regulated in the Ministerial Regulation (Law No. 19 year 2013, Article 37, verse 2: 17). As an actor of this agricultural insurance program, the Law mandates that insurance companies should be the state-owned enterprises and/or regional-owned enterprises. So, as one of the state-owned companies, Jasindo became the actor of agricultural insurance coverage.

The Central and Regional Governments, as mandated by the law, provide facilities for farmers to become the agricultural insurance participants, such as the ease of registration process to become a participant; the ease of access to insurance companies; socialization of insurance programs to farmers and insurance companies; and/or premium payment assistance.

Facilities provided by the central government through the Ministry of Agriculture are assistance in agricultural insurance premium payments. The government provides premium subsidies to farmers and cattle farmers who insure themselves to the appointed insurance companies. The amount of premium subsidies given is $80 \%$ of the premium, while the remaining $20 \%$ is the obligation of each farmer and rancher. 
The implementation was done in 2015 for rice plant microinsurance and 2016 for cattle microinsurance. The members of Rice Farming Insurance (AUTP) are the farmer groups who conduct farming activities, and the members of Cow Farming Insurance (AUTS) are the cattle farmers who conduct cattle breeding, either individual or in group (joined in the cooperative).

4) Model 4: Microtakaful of Infaq/Sadaqah Funding (Baituttamkin Tazkia)

Management model of mutual help fund organized by institutions in collaboration with Islamic insurance companies. The contribution of participants is paid using infaq/sadaqah funds.

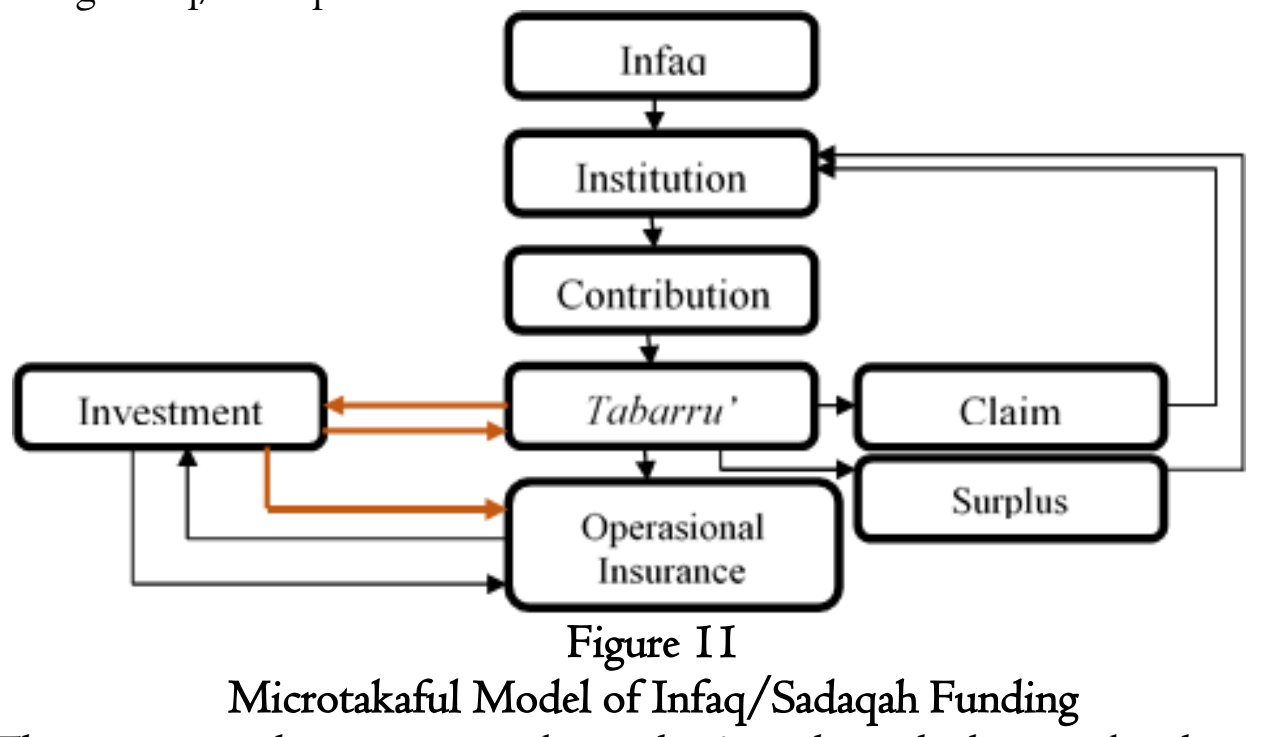

The institution has many members who join through the membership stage so that members are eligible for funding from the institution. Institutions apply the rules of infaq payments to institutions that are not compulsory. Infaq is collected by the institution once a week in assembly meetings (Arkam, 2017). This practice is one of the efforts to actualize love and affection between fellow human beings (Hafidhuddin, 2007: 70).

At the initial stage, the infaq is managed by the institution for the welfare of the members (Arkam, 2017), including:

I. Compensation for death amounted to IDR I00,000;

2. Compensation for sickness amounted to Rp.50,000;

3. Maternity benefits are given in the form of gift items; and

4. Marriage benefits are given in the form of gift items.

The management of members' infaq is conducted by each branch of the institution in each region in Indonesia. Currently, the management of infaq funds is carried out centrally with the principle "infaq is joint property, its utilization is 
regulated by the institution". The utilization of this members' infaq can be used to help other branches of the institution in terms of loan liquidity (Arkam, 20I7).

At present, the agency has collaborated with Islamic insurance to register all members with the microtakaful scheme using infaq as payment for their contribution. With a contribution of Rp. 8,000 per member, the compensation for death will be Rp. I,000,000 (Arkam, 2017). Therefore, microtakaful management is fully carried out by Islamic insurance.

5) Model 5: Microtakaful of Zakah Funding (Proposed)

Management model of mutual help fund organized by institutions in collaboration with Islamic insurance companies where the contribution of participants is paid by using zakah funds.

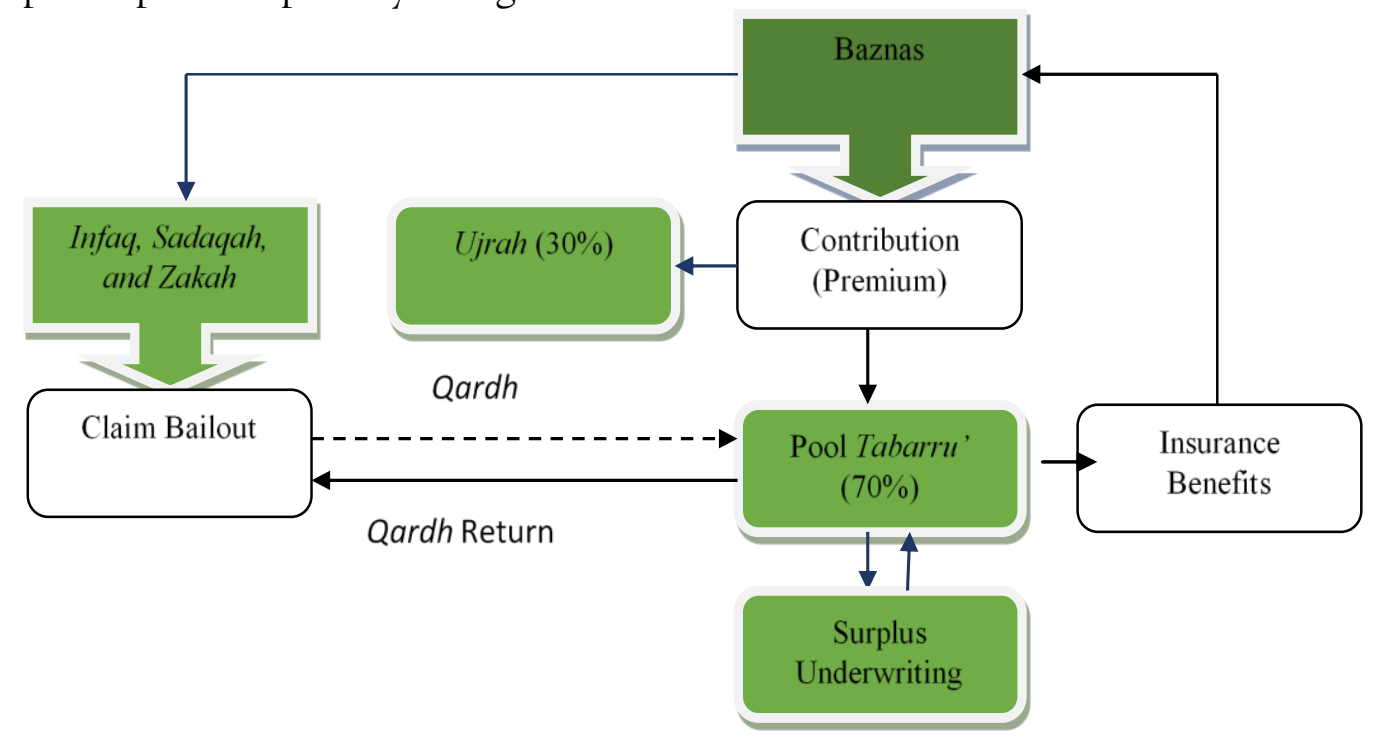

Source : Hasim (20I4), modified

Figure I2.

\section{Microtakaful Model - Zakat Fund}

The microtakaful model with zakah funding can be carried out by the National Zakah Agency (Baznas), which synergizes with Islamic insurance companies who manage microtakaful. The microtakaful scheme that is applied: simple benefits, simple registration process, economic contributions, and an immediate claim process so that it can help the community, especially those who are the target of zakah.

The management of microtakaful is fully carried out by Islamic insurance. Baznas submitted the mustahik data that was registered as a microtakaful participant. Payment of contributions made by Baznas by using the collected zakah 
funds. Hafidhuddin (2007: 68) stated that zakah is an important component in the economy of Muslims.

There is a slight difference in the management in Islamic insurance because the tabarru' funds are taken at $70 \%$ of the contribution. Also, the benefits of claims paid through Baznas are then distributed by Baznas to the eligible participants. When there is a surplus underwriting, it will be fully added to tabarru' funds. This is to increase the collected tabarru' funds. On the contrary, if there is deficit in tabarru' funds, then Baznas provides bailout claims from infaq, sadaqah, and zakat funds collected in Baznas. Then the Islamic insurance company will return the claim bail (qardh) from tabarru' funds.

The participants in this model are mustahik of zakah funds. This is in line with Hafidhuddin (2007: 70) that zakah is a right for mustahik, it can help the mustahik to improve their welfare of life.

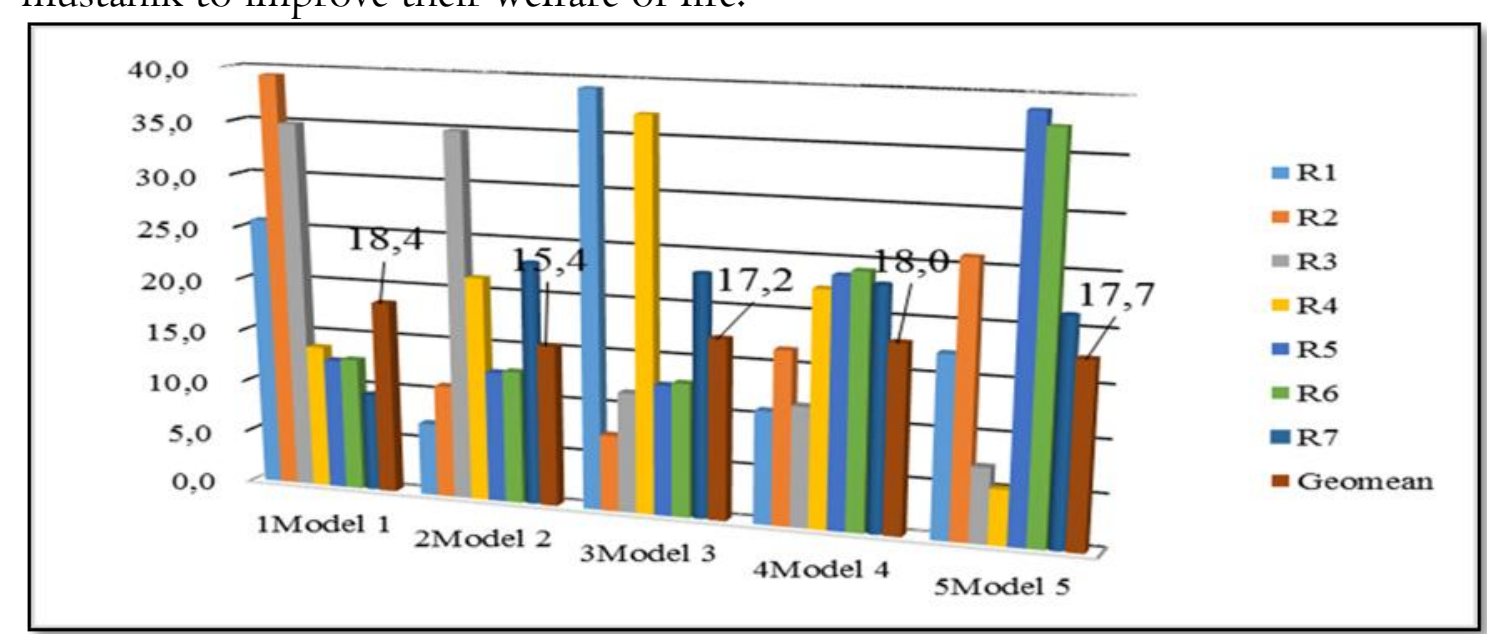

Figure I3

ANP Result of Microtakaful Model in Indonesia

Figure I3. shows individual assessment and consensus results. The results of the consensus stated that the Mikrotakaful Model with the most important priorities was the Microtakaful Model of the Independent Institution / Model I Management (I8.4\%). Then it is followed by the Microtakaful Model of Infaq/sadaqah Funding / Model 4 (18.0\%), the Microtakaful Model of Zakah Funding / Model 5 (17.7\%), Microtakaful with Government Support Model / Model 3 (I7.2\%), and the Microtakaful Model of Institution Funding / Model 2 (I5.4\%). However, the agreement of assessment was low $(\mathrm{W}=0.053)$.

Microtakaful Model of The Independent Management of Institutions is carried out on microfinance institutions that are in the initial phase and has a minimum risk: death, natural disasters and other calamities. As experienced by the 
Indonesian PBMT institution, the institution carries out its own management of the risk of the disaster. Management of the Ta'awun funds is fully handled by a special section formed by the institution.

The Microtakaful Model of Infaq/sadaqah Funding is recommended by experts because of the huge amount of the collected Infaq/sadaqah funds in Indonesia, which amounted to RpI.0 trillion (Baznas, 20I7: 6). In addition, the use of Infaq/sadaqah is not limited to mustahik only (Hafidhuddin, 20I7).

Microtakaful Model of zakah Funding occupies the third position as a model suggested by experts because the collected zakah funds in Indonesia reached Rp. 3.7 trillion (Baznas, 20I7: 6). However, the funding of the microtakaful contribution is limited to mustahik of zakah only (Hafidhuddin, 2017).

The Microinsurance Model with Government Support occupies the fourth position as the model suggested by experts. Law No. I9 Year 2013 gives a mandate to the government to provide protection and empowerment to the farmers. It is the mandate of the law "the poor and neglected children are maintained by the state". The last, the Mikrotakaful Model of Institutional Funding occupies the fifth position as the model suggested by experts.

\section{E. CONCLUSION}

This study concludes that the microtakaful program fulfills the Maqashid Shariah with the main priority of protecting the soul. The operational aspect of microtakaful which is a priority is Akad. The priority sub-criteria on the contract is the mudharabah musytarakah contract. The priority sub-criteria for Underwriting are simple processes and easy-to-understand language. The priority sub-criteria of the Donor Institution are the Zakah Agency. The priority sub-criteria for the Participants are the poor. The priority sub-criteria for investment are sukuk (Islamic bonds). The priority sub-criteria on Facility Needs are Systems (IT). Lastly, the priority alternative of microtakaful models in Indonesia is the microtakaful model of an independent institution.

According to the study results, this study gives recommendations to the microtakaful institutions to comply with the shariah requirements and government regulation. Microtakaful companies must provide the best service for all participants so that the benefits can be utilized by them. Therefore, the penetration of microtakaful can meet the target of reaching a very large number of middle and poor people. The Institution Management Model become the best alternative model because it provides flexibility to institutions to manage the microtakaful funds. Provisions can be more flexible by following the rules of the institution. 
However, this model also still has to meet large numbers of participants, and the risk management must be handled professionally. Furthermore, this model is more suitable for one institution that has fulfilled a large number of participants but is less suitable for an institution in the form of associations or joint institutions.

\section{REFERENCES}

Abdelkader, I.B., Salem, A.B.(2013). Islamic Vs Conventional Microfinance Institutions: Performance Analysis in MENA Countries. International Journal of Business and Social Research (IJBSR), Volume -3, No.5.pp:219-233

Ahmed, M.H.(2016). Micro Takaful Insurance As A Tool To Guaranteeing Financing And Protecting Micro Enterprises. Journal of Business \& Financial Affairs Volume 5. pp. I-II.

Ascarya, et al (2016). Holistic Financial Inclusion Based On Maqashid Shariah

Through Baitul Maal Wa Tamwil. Workshop on Islamic Finance:

Regional Perspectives, National University of Singapore, Singapore, I6-I7 February, 2016.

Ascarya. (2013). The Persistent Lack Of Profit And Loss Sharing Financing In Indonesia's Islamic Banks. International Journal of Islamic and Middle Eastern Finance and Management.

Ascarya. (20I4). In Search Of Sustainable Conventional And Islamic Microfinance Models For Micro Enterprises. Forum Riset Syariah 2014.

Ascarya, et al (2015). Designing Holistic Financial Inclusion Based On Maqashid Shariah. Inaugural Annual Symposium on Islamic Finance 2015 "Islamic Finance: A Catalyst for Shared Prosperity". Istanbul.

Aziz, A dan Mohamad, S. (2013). Fulfillment of Maqashid Al-Shariah via Takaful. Munich Personal RePEc Archive MPRA Paper No. 47776, posted 24. June 2013 04:05 UTC. Pp.5-7

Badan Amil Zakat Nasional.(2016). Buku Statistik Zakat Nasional 2015.

Badan Amil Zakat Nasional.(2017). Buku Statistik Zakat Nasional 2016.

Badan Pusat Statistik. (2015). Statistik Desa yang Mengalami Bencana Alam. Jakarta, DKI : Penulis.

Badan Pusat Statistik. (2016). Berita Resmi Statistik: Profil Kemiskinan di Indonesia September 20I5. No. 05/0I/Th. XIX. Jakarta, DKI : Penulis. 
Badan Pusat Statistik. (2017). Berita Resmi Statistik: Profil Kemiskinan di Indonesia September 2016. No. 05/0I/Th. XX. Jakarta, DKI : Penulis.

Bakhtiari, S. (2013). Microinsurance And Microtakaful: Strategies For Poverty Reduction Towards Sustainable Development. OIDA International Journal of Sustainable Development. pp. 93-I00

Erlbeck, A., et al. (20II). Microtakaful: Field Study Evidence And Conceptual Issues. $\quad$ http://www.rug.nl/research/globalisation-studies groningen/research/conferencesandseminars/conferences/eumicrofinconf 201 I/papers/I3.erlbeck-altuntas-berrystolzle.pdf. pp. I-29.

Fatwa Dewan Syariah Nasional Majelis Ulama Indonesia No 53/DSNMUI/III/2006 tentang Akad Tabarru’ Pada Asuransi Syariah.

Forum Zakat. (20I2). Cetak Biru Pengembangan Zakat di Indonesia 20I I-20I5. Jakarta: Forum Zakat.

Gor, N. (2013). Microtakaful-Islamic Insurance For Deprived: Innovation, Sustainability And Inclusive Growth. International Journal of Business, Economic and Law Vol. 3, pp. I8-24.

Hasim, H. M. (20I4). Microtakaful as an Islamic Financial Instrument, for Poverty Alleviation in Iraq. Middle East Journal of Scientific Research, 2I(I2), 23I5-2325.

IFSB dan IAIS. (2015). Issues In Regulation And Supervision Of Microtakā ful (Islamic Microinsurance).

Iqbal, Z. (20I4). Enhancing Financial Inclusion through Islamic Finance. Paper, presented at Financial Inclusion Conference, Turkey.

Ismal, R. 2013. Islamic Banking in Indonesia : New Perspective on Monetary and Financial Issues. Singapore: John Wiley and Sons Singapore Pte.Ltd.

Kailani, M.I., (1998). The Book of Zakat (Precepts Dealing with Poor Due). Riyadh:Darussalam.https://dI.islamhouse.com/data/en/ih_books/single 2/en_The_Book_of_Zakaat.pdf

Karim Consulting Indonesia. (2017). Islamic Insurance Outlook 2017.

Kementerian Agama RI, Direktorat Jenderal Bimbingan Masyarakat Islam, Direktorat Pemberdayaan Zakat. (20I3). Standarisasi Amil Zakat Di Indonesia Menurut UU No 23 Tahun 201 I Tentang Pengelolaan Zakat.

Masrifah, A. R. (2016). Efisiensi BMT Pesantren dalam Pengelolaan Harta Usaha Mikro. Tesis. Sekolah Tinggi Ekonomi Islam Tazkia. Tidak diterbitkan.

Musari, K. 20I5. Sukuk For Microfinance Through Linkage Program: Case Study In Indonesia. The IOth International Conference Islamic Economic And 
Finance (ICIEF) Institutional Aspects of Economic, Monetary and Financial Reform. Pp I-I2

Patel, S. (2004). Takaful and Poverty Alleviation. ICMIF. United Kingdom.

Patel. (2012). Mikrotakaful : Time To Make A Real Difference To People's Livelihoods.

Pew Research Center's Forum on Religion \& Public Life. (20II). The Future of the Global Muslim Population Projections for 2010-2030.

Puskas BAZNAS.2016. Outlook Zakat Indonesia 2017. Puskas BAZNAS. Jakarta. Qardawi, Y. (I99I). Hukum Zakat : Studi Komparatif Mengenai Status dan Filsafat Zakat Berdasarkan Quran dan Hadits. Jakarta : Litera Antarnusa.

Qardawi, Y. (2006). Hukum Zakat Cetakan ke-9. Bogor :Pustaka Litera AntarNusa.

Rom, N. A. M., Rahman, Z. A. (2012). Financial Protection for the Poor in Malaysia : Role of Zakah and Micro-takaful. JKAU: Islamic Econ, Vol. 25 No. I, pp. II9-I40.

Rusydiana, A., Devi, A. (2017). Development Strategy of Micro-takaful Institutions: Case Study Working Group Indonesia. Etikonomi Volume I6 (2), Oktober 2017 P-ISSN: I4I2-8969; E-ISSN: 246I-077I, pp. 265 - 278. http://journal.uinjkt.ac.id/index.php/etikonomi.

Saaty dan Vargas. (2006). Decision Making With The Analytic Network Process Economic, Political, Social And Technological Applications With Benefits, Opportunities,Costs And Risks. USA: Springer.

Sarwat, A. (2016). Seri Fiqih Kehidupan : Zakat. Rumah Fiqih Publishing: Jakarta.

Sukmana, R., Hidayat, S.E. (20I4). Challenges and Opportunities in Developing Microtakaful in Muslim Majority Country: A Case Study of Indonesia. The I Ith Harvard University Forum on Islamic Finance. pp. I-I4

Suryanto, T., Purnamasari, F., \& Kurniawan, M. (2018). Tax Revenue and Disparity: How to Improvement Income Inequality in Islamic Perspective. Asian Journal of Social Sciences and Management Studies, 5(2), 65-7I.

Sula, M.S.(2016). Principles Of Islamic Insurance (Prinsip-Prinsip Asuransi Syariah) Life, General and Social Insurance. Syakirsula Institute: Depok.

Surat Edaran Otoritas Jasa Keuangan No 9/SEOJK.05/20I7 Tentang Produk Asuransi Mikro dan Saluran Pemasaran Produk Asuransi Mikro.

Swartz, N.P. and Coetzer, P. (2010). Takaful: An Islamic insurance instrument. Journal of Development and Agricultural Economics, 2(I0), pp. 333-339, October, 20I0. Available at http://www.academicjournals.org/JDAE 
(DindinJaenudin ${ }^{1}$, Achmad Firdaus ${ }^{2}$, Farit M. Afendi ${ }^{3}$, Bayu Taufiq Possuma ${ }^{4}$ )

Syahatah, H.(2004). Akuntansi Zakat : Panduan Praktis Penghitungan Zakat Kontemporer. Pustaka Progressif : Jakarta.

Takaful Insurance of Africa. (I November, 2012). Slideshare. Retrieved from Takaful: An Opportunity to Extend the Provision of Microtakaful: http://www.slideshare.net/icmifmicroinsurance/takaful-an opportunityto-extend-the-provision-of-microtakaful. Diakses tanggal 29 April 2017

Tanjung, H., Devi, A. (2013). Metodologi Penelitian Ekonomi Islam. Jakarta. Gramata Publishing. 